\title{
AUTHORSHIP AND LANGUAGE IN CONTEMPORARY ARCHITECTS' BOOKS
}

\section{A B S T R A C T}

This paper examines theoretical, graphical, and material dimensions of the contemporary print culture of architecture with a focus on one work from a variety of European practices. It regards the contemporary architect's book as a speculative and discursive design object. Michel Foucault, particularly in his works, What is an Author? (1969) and The Archaeology of Knowledge (1972), criticises that while constructing an author's body of works, alternative and unclassified genres are omitted from the domain and the texts attached to the single name belong to a system of homogeneity, filiation, and reciprocal explanation. Yet the contemporary architect's book expands the borders of genres by comprising unconventional materials, such as musical notes, artistic photographs, paintings, technical and scientific diagrams, official reports, building regulations, newspaper articles, and advertisements, as well as combining texts and photographs from co-workers, partners, clients, and users, rather than emerging as the product of a single author. The paper interprets the use of various forms of graphical narration and the coalescence of novel terminology and jargon as a contribution to the power of language and discursive formation. 


\section{INTRODUCTION}

Architecture media, including but not limited to exhibitions, advertisements, documentaries, books, journals, and magazines, contribute to the production, promotion, and circulation of knowledge in today's age of image economy. They intend to make the audience encounter with and speculate on architecture culture, as much as they emerge as personal statements and design approaches. The printed media in particular have currently expanded as a critical site of producing knowledge, generating emergent ideas, promoting the architects as a brand, and questioning established canons and norms. ${ }^{1}$ This paper examines the theoretical, graphical, and material dimensions of contemporary print culture of architecture, namely the architect's book. The paper tackles one book from a variety of European architects and architecture offices: $S, M, L, X L$ by the Office for Metropolitan Architecture - OMA (1995), Farmax by MVRDV (1998), Short Cuts by Didier F. Faustino (2008), Yes is More by BIG (2009), Agenda by JDS Architects (2011), Architecture Concepts: Red is Not a Color by Bernard Tschumi (2012).

Monographs, conventionally, reveal and expose orthographic sets, sketches, and various big-sized photographs and renders, which illustrate the buildings as finished and glossy products. Addressing a wide range of readers, from clients to fellow architects and students, they are mainly aimed at advertising, promoting, archiving, and representing purposes. They use an abundance of images, since, in our image-laden cultural domain, the built environment is primarily consumed as a visual effect. These case studies were chosen exclusively because they differ from conventional architect's books in terms of format and content, by combining various genres, such as monograph, manifesto, exhibition catalogue, and magazine. The paper regards the contemporary architect's book as a speculative, discursive, visual, and physical design object. Through a Foucauldian reading, it argues that the book emerges as a collective, social, and cultural instrument.

\section{THE AUTHORITY OF THE SINGLE AUTHOR}

In his 1969 essay "What is an Author?" Foucault begins unfolding the concept of author-function, which he later elaborates further in one of his seminal works The Archaeology of Knowledge (1972). He dwells on the construction of an author's body of works: 
'A name can group together a number of texts and thus differentiate them from others. The fact that a number of texts were attached to a single name implies that relationships of homogeneity, filiation, reciprocal explanation, authentification, or of common utilisation were established among them.'2

As he argues, anonymous writings and alternative genres are conventionally omitted from the domain of an author; in other words, one's works are extracted from these materials. Thus, unconventional materials, such as invoices and draft notes, are not counted in the body of mainstream literary and scholarly works of an author. Foucault asserts that,

'Is everything he wrote and said, everything he [the author] left behind, to be included in his work? ... If we wish to publish the complete works of Nietzsche, for example, where do we draw the line? Certainly, everything must be published, but can we agree on what 'everything' means? We will, of course, include everything that Nietzsche himself published, along with the drafts of his works, his plans for aphorisms, his marginal notations and corrections. But what if, in a notebook filled with aphorisms, we find a reference, a remainder of an appointment, an address, or a laundry bill, should this be included in his works? Why not?’3

Refashioning Foucault's remark, the contemporary architect's book expands the framework of genres by including usually ignored materials as Foucault elaborated, and by comprising unconventional materials, such as official reports, building regulations, advertisements, newspaper articles, satellite images, maps, technical and scientific diagrams, office dialogues, public

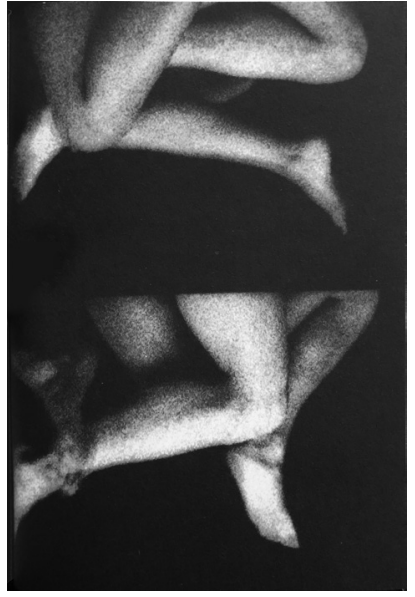

Fig. 1. Didier Faustino. 2008. Short Cuts. Blou: Monografik Éditions.

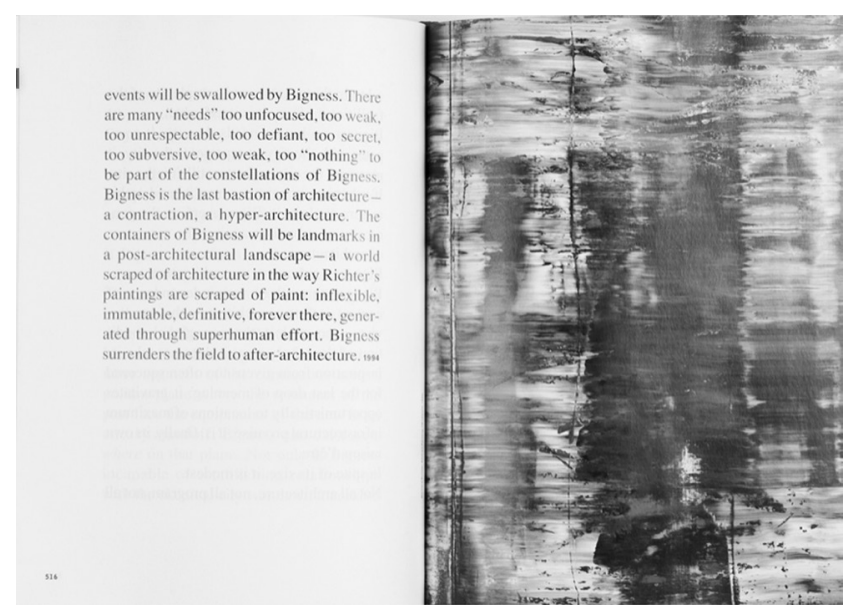

Fig. 2. OMA, Rem Koolhaas and Bruce Mau. 1995. $S, M, L, X L$. New York: The Monacelli Press. 
comments, and even clients' photographs. For example, due to its content, it is very hard to describe Faustino's Short Cuts as a conventional architect's book, since the pages contain architectural drawings of plans, sections, axonometry, and perspective, renderings, photographs of cityscapes, spaces, furniture, art objects, people, and fragments of human body with no page numbers (Figure 1). Each image is placed on one or two pages, while some pages are left blank. Moreover, OMA's 1,344-page seminal work, $S, M, L, X L$, which was produced with the Canadian graphic designer Bruce Mau, merges the genres of diary, novel, dictionary, history, and monograph. The dense, scholarly, and expensive book is regarded as an authority in its thesis and a significant contribution to architectural discourse and print culture. Its image-laden form and montage-like layout are created by the newly-developing digital techniques of transforming specific media into another in architecture culture, as well as the cinematic technique, which was the dominant media of the twentieth-century (Figure 2). According to Rem Koolhaas, montage is the common ground of architecture, text, and film, as it allows different media to combine but also maintain their individual representational features. ${ }^{4} \mathrm{He}$ deals with the coalescence of film, text, and architecture, due to his profession as a journalist and screenwriter before working as an architect. ${ }^{5}$ Following $S, M, L, X L$, MVRDV's Farmax, is another example of bulky but sophisticated architect's books, with a total of 736 pages. Covered with an abundance of images, it is hard to discover the texts throughout the pages (Figure 3). The book does not only consist of their architectural works, but also reveals their global research and analysis by means of photographs, architectural drawings, diagrams, calculations, and catchy phrases. It does not have a single author (though the book is edited by three people), but various authors that contribute to the book with different contents, such as texts, research, data, images, and projects. This representation

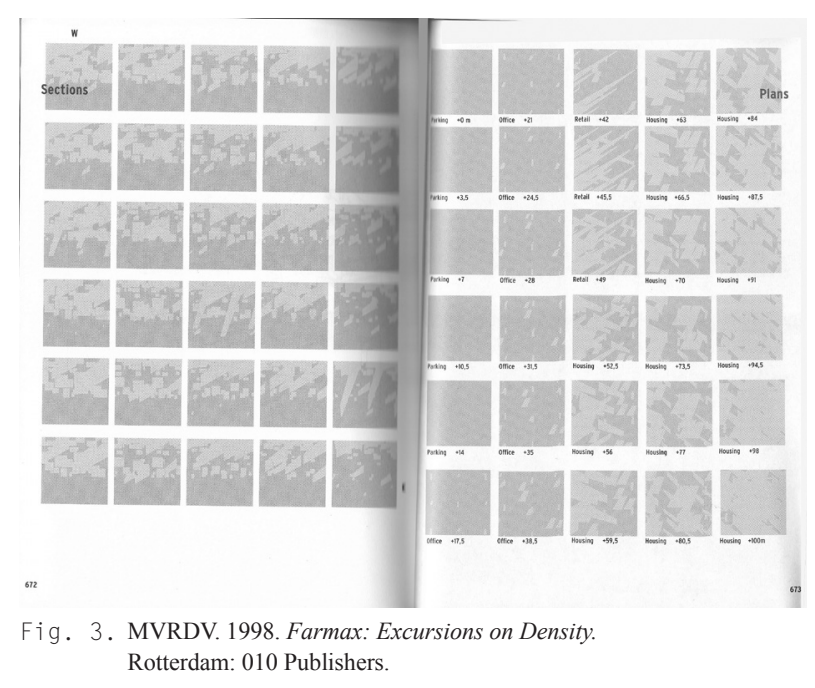


of architecture derives from MVRDV's seeing architecture as a research, situated between function, aesthetics, and a critique of the world. ${ }^{6}$ In a sense, it associates with Foucault's argument of what can be counted as the body of mainstream scholarly works that construct the name of the author. Overturning power relations, in OMA's and MVRDV's sense, discourse seems to be formed through anonymous tags, notes, posters, photographs, as well as collaborative texts, analysis, and research. As Foucault further elaborates,

'In our culture, the name of an author is a variable that accompanies only certain texts to the exclusion of others: a private letter may have a signatory, but it does not have an author; a contract can have an underwriter, but not an author; and, similarly, an anonymous poster attached to a wall may have a writer, but he cannot be an author. In this sense, the function of an author is to characterise the existence, circulation, and operation of certain discourses within a society. ${ }^{97}$

Case studies analysed in this paper re-evaluate Foucault's notion of authorfunction, since the architect's book includes texts and photographs from coworkers, partners, clients, and users, rather than being the production of a single author. They, in a sense, question the singular power attained to the name of the author that functions as a contributor to the construction, dissemination, and operation of knowledge and discourse within society. In Faustino's Short Cuts, this overturning of the singular power of the author is particularly observed, since the content of the book renders the author ambiguous. A short text is placed only inside the front and back covers, leaving the rest of the book to the interpretation of the reader, as it states in capital letters:

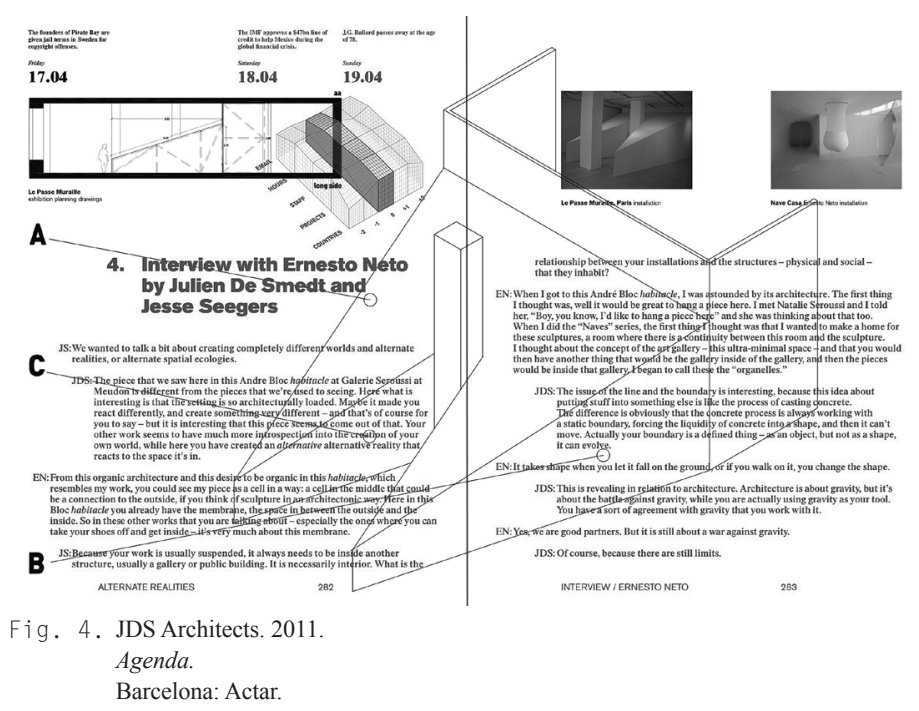


'There is no human mind without a body. In this time of hygienapolis, you must recover your awareness of the physical world. One way is to produce fragile objects, systems, spaces which are meaningful only through the body, being all at once physical, social and political. Architecture may be a tool to emphasize our senses and sharpen our consciousness of reality, which tends to be erased by over-information, egocentrism and control. Experiencing fragility.'

\section{THE POWER OF LANGUAGE}

The projects that are included in the books examined in this paper are assembled according to a thematic narrative, rather than a chronological order. The only exception is JDS Architects's Agenda, which is designed as an architecture diary, journal, a monograph, and a catalogue of 365 days. Both personal and subjective, the book illustrates the projects chronologically (Figure 4). The fragmental structure of other books makes the layout differ from one another on every single page. The content of Farmax is organised through the term density, whereas $S, M, L, X L$ is arranged in relation to various architectural scales. The absorbing layouts and distinctive typographies challenge conventional design and graphical approaches. The architects handle established codes, norms, and design methods critically, and look for a new method of design and form of expression. They promote their ideas using media, from books and web sites to exhibitions and talks. In Yes is More, Bjarke Ingels, the founder of BIG, uses a slippery and shifting ground of daily language, such as the linguistic binaries of rational and irrational, serious and humorous (Figure 5). The use of the language

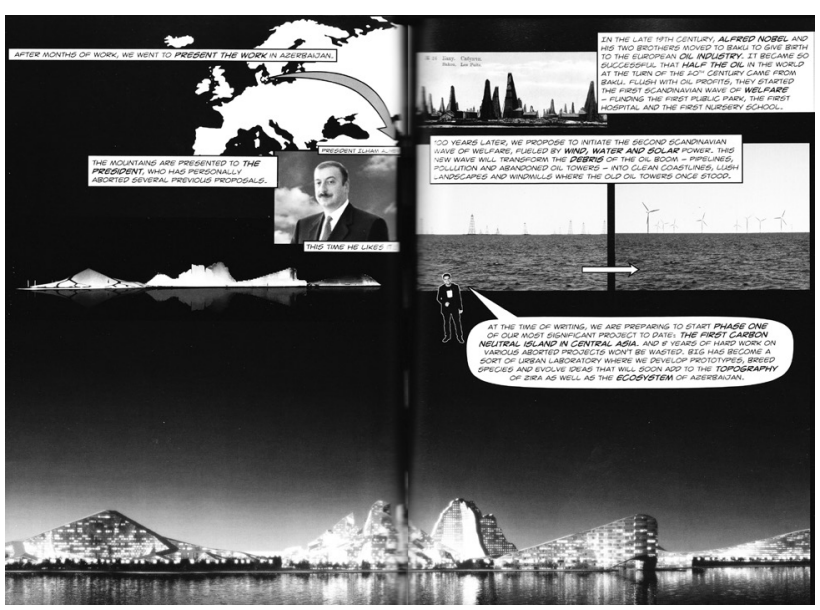

Fig. 5. BIG. 2009

Yes is More: An Archicomic on Architectural Evolution.

Cologne: Taschen. 
of mass culture leads to the impression that the book is not only a medium for advertising and promoting their architecture. Similarly, Koolhaas notes that $S, M, L, X L$ had sold 140,000 copies due to its ability to allow the public to access the world beyond architecture. ${ }^{9}$ Like Yes is More, any audience which engages in current issues that shape the architectural canon can benefit from the book. Posing a variety of arguments ranging from the scale of an exhibition space to the urban scale, it is situated in-between architecture as a physical construction and critical theory.

Developing a subjective and personal narrative like the diary format of Agenda, Yes is More embraces the format of a comic strip. The book has comic book typography with dynamic, handcrafted, bold emphasised capitalized letters and extensive use of punctuation marks. Commentary texts are divided into two or three sentences, and are placed into text boxes or speech balloons. Ingels explains that the format of the book was inspired from the method of architectural lecturing - a visual and verbal combination, which also explains his use of first person plural narration:

'Most publications, because of layout reasons, separate the two. Either they have a long essay that you read separately from the images you see afterwards, or we read a little intro piece and then captions. Instead of separating the visual, diagrammatic, graphic from the verbal, we tried to combine it, simply by turning a lecture into a book. ${ }^{10}$

His use of daily and spoken language in speech balloons and verbal comments in text boxes can be seen as a current contribution to the power of language and discursive formation in the context of design.
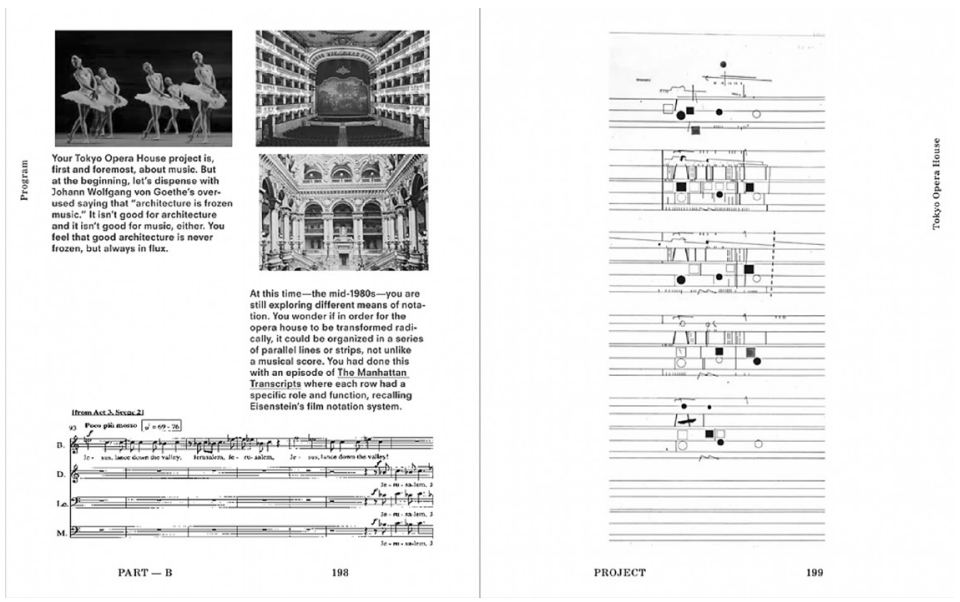

Fig. 6. Bernard Tschumi. 2012.

Architecture Concepts: Red is Not a Color. New York: Rizzoli. 
Widely elaborated by Foucault in The Archaeology of Knowledge, the term "discourse" includes the spoken and written language within the context of knowledge construction and power relations in society, yet reveals differences, disruptions, and breaks ${ }^{11}$ :

'Discursive formation appears both as a principle of division in the entangled mass of discourses and as a principle of vacuity in the field of language. [...] The discursive formation is not therefore a developing totality, with its own dynamism or inertia, carrying with it, in an unformulated discourse, what it does not say, what it has not yet said, or what contradicts it at that moment; it is not a rich, difficult germination, it is a distribution of gaps, voids, absences, limits, divisions. ${ }^{12}$

This paper handles the use of various forms of graphical and textual narration and the coalescence of divergent terminology and expressions as related to the power of language. In Tschumi's Architecture Concepts, for example, unlike BIG's Yes is More, the emphasis is put on the second person singular narration, "you" in an unconventional way (Figure 6). This kind of narrative points to the power of language, as it pacifies the author and transforms the reader into an active subject. As Tschumi explains:

'Each part presents an 'insider' story - the story of the thoughts and events that propelled the development of each architectural project. Much of the narrative is written in the second person as if in a talk or discussion addressed to one or more individuals. [...] the text is addressed to a reader who is the protagonist in the narrative/adventure/journey in. [... ] the use of 'you' is intended to draw the reader in, bringing him or her close to some of the questions raised by architecture today.'

Furthermore, commentary and interpretation in texts, although they are dismissed from discursive formation in conventional understanding, reveal subtextual articulations and give the opportunity to say additional words over the finalised work. ${ }^{14}$ In Yes is More, commentary covers a large area, by a small figure of Ingels as the narrator, which is encountered frequently throughout the pages. By means of dialogue bubbles and narrative text boxes in the comic book format, he shares previously untold stories about BIG's work otherwise unavailable to the public. 


\section{CONCLUSION}

Pioneered by $S, M, L, X L$, the contemporary architect's books blend divergent media throughout the pages from their front covers to the back: cartoon figures, speech balloons, computer games graphics, screen shots, advertisements, architectural drawings, renders, photographs, satellite views, paintings, maps, diagrams, ideograms, magazine pages, newspaper headlines, catchphrases, declarations, official reports, cutout texts, short essays, and interviews. Set in a plural and heterogeneous context as an object and subject, the books deconstruct and reconstruct textual and visual spaces of architecture. Reconfiguring format, layout, content, and medium, they blur the borders of the genres of monograph, manifesto, magazine, journal, analysis, report, exhibition guide, and catalogue. The current shift in the graphical communication of architecture, from orthographic drawings to an abundance of images, points to the hypothesis that the target group of these books is not a limited number of professionals, but mass culture. The architects aim at reaching to a wider audience and initiating a dialogue with them. The printed medium thus becomes a crucial site of research and analysis, while addressing the general public.

Being much more than promoting and advertising the projects, the analytic and discursive contents of these books leave the tackled topics suspended for further discussions. In this sense, they act as political, social, and cultural constituents for rethinking the urban fabric and the environment, as well as they contribute to the generation of new architectural terminology. As Foucault argues,

'The notion of discontinuity assumes a major role in the historical disciplines. For history in its classical form, the discontinuous was both the given and the unthinkable: the raw material of history, which presented itself in the form of dispersed events - decisions, accidents, initiatives, discoveries; the material, which, through analysis, had to be rearranged, reduced, effaced in order to reveal the continuity of events. Discontinuity was the stigma of temporal dislocation that it was the historian's task to remove from history. It has now become one of the basic elements of historical analysis. ${ }^{, 15}$

In this sense, with their juxtaposed mediums and amalgamated genres, we might read these architect's books as disruptions, suspensions, voids, and gaps, forming the discourse of their time. 

production, ed. Beatriz Colomina (New York, NY: Princeton Architectural Press, 1988), 23. John D. Caputo, and Merold Westphal (New York: Fordham University Press, 1992), 304-305. Ibid., 302. Whitten Overby, “A Multimedia Panopticon: Media, Translation, and History in OMA’s S,M,L,XL and the Arnhem Prison," Journal of Architectural Education 69(2) (2015): 169.

Donald McNeill, "Content and the Architect's Book," in The Global Architect: Firms, Fame and Urban Form, ed. Donald McNeill (New York, London: Routledge, 2009), 99. Aaron Betsky, "MVRDV: The Matrix Project," in Reading MVRDV, ed. Véronique Patteeuw (Rotterdam: Nai Publishers, 2003), 13. 
Bjarke Ingels, “Responses.” Clog 1 (2011): 105.

Michel Foucault, The Archaeology of Knowledge. trans. Alan M. Sheridan Smith (London, New York: Routledge, 1972), 220-221.

Michel Foucault, The Archaeology of Knowledge, 134.

Bernard Tschumi, Architecture Concepts: Red is Not a Color (New York: Rizzoli, 2012), 7.

Michel Foucault, The Archaeology of Knowledge, 135-136.

Michel Foucault, The Archaeology of Knowledge, 9. 
Betsky, Aaron. "MVRDV: The Matrix Project.” In Reading MVRDV, ed. Véronique Patteeuw, 1023. Rotterdam: Nai Publishers, 2003.

Colomina, Beatriz. "Introduction: On Architecture, Production and Reproduction." In Architecture production, ed. Beatriz Colomina. 6-23. New York, NY: Princeton Architectural Press, 1988.

De Smedt, Julien. Agenda. Barcelona: Actar, 2011.

Faustino, Didier F. Short Cuts. Blou: Monografik Éditions, 2008.

Foucault, Michel. "What is an Author?” In Modernity and Its Discontents, eds. James L. Marsh, John D. Caputo, and Merold Westphal, 299-314. New York: Fordham University Press, 1992.

Foucault, Michel. The Archaeology of Knowledge. Trans. Alan M. Sheridan Smith. London, New York: Routledge, 1972.

Ingels, Bjarke. Yes is More: An Archicomic on Architectural Evolution. Cologne: Taschen, 2009.

Ingels, Bjarke. "Responses." Clog 1 (2011): 102-11.

Koolhaas, Rem and Bruce Mau. S,M,L,XL. New York: The Monacelli Press, 1995.

Koolhaas, Rem. "In Conversation with Beatriz Colomina." El Croquis 134-135 (2007): 348-77.

Maas, Winy, Jacob Van Rijs, and Richard Koek. Farmax: Excursions on Density. Rotterdam: 010 Publishers, 1998.

McNeill, Donald. "Content and the Architect's Book." In The Global Architect: Firms, Fame and Urban Form, ed. Donald McNeill, 99-103. New York, London: Routledge, 2009.

Overby, Whitten. “A Multimedia Panopticon: Media, Translation, and History in OMA's S,M,L,XL and the Arnhem Prison." Journal of Architectural Education 69(2) (2015): 167-177.

Tschumi, Bernard. Architecture Concepts: Red is Not a Color. New York: Rizzoli, 2012. 


\section{ESTETIKA ODRŽIVOSTI: ARHITEKTURA KAPSULE U GRADU I U PRIRODI Peter Šenk}

Arhitektura najmanjih mesta za stanovanje je u poslednje vreme izuzetno popularna tema. Kada su najmanja mesta za stanovanje kompaktna, dobro opremljena, povezana na mrežu, strukturno, funkcionalno i vizuelno prepoznata kao jedna stvar, privremena i pokretna ili prenosiva, mogu se označiti kao arhitektura kapsule. Budući da su po svojoj prirodi privremena, ova najmanja mesta za stanovanje, skloništa, redizajnirane kontejnerske jedinice, posebne tehnološke konstrukcije, paraziti i druge manifestacije koncepta kapsula obuhvataju logiku tehnoloških objekata s izrazitim arhitektonskim izrazom. To je, istovremeno, manifestacija pravila održivog dizajna, održive arhitekture i održivosti uopšte. U ovom kontekstu slučaj najmanjih mesta za stanovanje pokazuje svoju razliku u odnosu na druge održive arhitektonske pristupe i estetike. Podredjuje uopšteno održive pristupe sa izraženim značajem lokaliteta unutar globalnih sila, obično se oslanjajući na kontekst - lokaciju, lokalnu kulturu i karakteristike životne sredine itd. Estetski režim trenutnih, promenljivih, kontekstualnih i autonomnih arhitektonskih struktura se može posmatrati kao estetika drugosti, koja ih povezuje sa nasledjem egzistencijalnih eksperimenata modernog pokreta, novim brutalizmom, radikalnim eksperimentima 1960-ih i drugim avangardnim i neoavangardnim praksama dvadesetog veka, ali čvrsto postavljenim u kontekstu individualizovane, neodredjene, raspršene i dvosmislene savremenosti.

KLJUČNE REČI: ESTETIKA PROMENE, KAPSULE, NAJMANJA MESTA ZA STANOVANJE, MINIMALAN TRAG, DRUGOST, ESTETIKA ODRŽIVOSTI

\section{ESTETIKA I KULTUROLOŠKI ASPEKTI BAUHAUSA: \\ KA NOVOJ KONCEPCIJI}

\section{Christiane Wagner}

Ovaj članak pokriva nove mogućnosti Bauhaus pogleda na svet: stvaranje novih oblika za prikazivanje ljudskih ideala kroz fokus na estetiku i tehnologiju, u kombinaciji sa Nimajerovim (Niemeyer) uticajem na arhitekturu i dizajn. Novi stilovi i oblici nastali su kao izdanci Bauhausa, prenoseći vrednosti svake kulture kroz izgradnju kolektivne „slike“ sveta. Bauhaus današnjice izražava industriju kulture, dijalektički razmatrajući inovaciju i primenjenu umetnost kao put od modernog dizajna industrijske revolucije do „eko dizajna“. U tom smislu, Bauhaus je još uvek značajan po svojoj ulozi, povezujući umetnost, tehnologiju i industriju. Inovacija kao dinamično odredjivanje trenutka, prisutna u svim epohama, se shvata kao moćna sila za održavanje tradicije. Pored hronološkog zapisa o uticaju Bauhausa, razmatraju se i značajni Nimajerovi projekti. Na kraju su prikazane dve perspektive ,raskola“ izmedju arhitekture i tehnologije. Prva perspektiva se odnosi na ljudsku sposobnost stvaranja modela u arhitektonskoj praksi za usvajanje kao konfiguraciju prostora. Druga se odnosi na evoluciju tehnologija koje vode do toga da zamišljeno postaje stvarnost kroz vreme, kako je to opisao Hegel (1823).

KLJUČNE REČI: IZRADA PO MERI, TEHNOLOŠKI RAZVOJ, PROSTOR-VREME, NOVI OBLICI

\section{KLASIČNA ARHITEKTURA U OKVIRU KANTOVSKE ESTETIKE: IZMEĐU LIOTARA I RANSIJERA}

\section{Helen Tatla}

Potencijal koji je svojstven klasičnoj arhitekturi da predstavlja glavni arhitektonski izraz zapadne kulture budući da je grčka antika nastala zbog svog dualnog karaktera: iako izvire iz iskonskog jedinstva stvari izraženih mitom i religijom u arhaičnim vremenima, ona dobija svoj završni oblik u petom veku p. n. e., kao simbol demokratije i harmonične artikulacije sveta na osnovu filozofskog mišljenja. 
Postavljajući avangardnu umetnost u sferu kantovske uzvišenosti, Žan Fransoa Liotar (JeanFrancois Lyotard) se fokusira na nemogućnost apsolutnog odnosa razuma i percepcije ili između razmišljanja i slike, u savremenosti. On smatra da se u slučajevima kada se to dogodi radjaju politička čudovišta. On povezuje postmoderne izraze klasicizma u arhitekturi sa Frojdovim „Tumačenjem snova“" i kantovskom lepotom.

Pristup Žaka Ransijera (Jacques Ranciere) kantovstvu na osnovu estetskog razmatranja modernosti suprotan je onome koji je predložio Liotar. Umesto uzvišenog, Ransijer povezuje lepo s pukotinom izmedju razmišljanja i percepcije. U tom pogledu, fragmenti prošlosti mogu da podstaknu kreativni proces u sadašnjosti.

Cilj ovog istraživanja je da doprinese dijalogu o obnovljenom pristupu ulozi klasicizma u arhitekturi danas.

KLJUČNE REČI: KLASIČNA ARHITEKTURA, KANT, LIOTAR, MODERNOST, POLITIKA, POSTMODERNOST, RANSIJER

\section{FLUIDNO STANJE ARHITEKTURE}

\section{Bojana Jerković-Babović}

Ovaj rad se bavi promenama u kriterijumima arhitektonske estetike, transformacija statičnih u dinamične vrednosti podjednako figurativnih i nefigurativnih aspekata savremene arhitekture i njenog konteksta. Fluidno stanje arhitekture odnosi se na prepoznavanje konstantne promenljivosti koja se manifestuje u relacijama arhitekture i savremenom kultuloroškog konteksta globalizacije. Savremeni kontekst dinamizuje perceptivna iskustva svakodnevnice, uslove života i načine prostornih aproprijacija. U skladu sa tim, novi fenomeni umreženosti koji se manifestuju na informacionim, komunikacionim i prostornim nivoima transformišu grad i arhitekturu u konstantne procese tokova, kojima se njihovi elementi dematerijalizuju u nove fluidne, promenljive karakteristike. Vredosti arhitektonske estetike istovremeno se transformišu ka afirmaciji dogadjaja i efekata naspram statične formale celine, od objektivnih do intersubjektivnih estetskih prostornih iskustava.

Ovaj rad se bazira na hipotezi da savremenu arhitekturu karakteriše gubitak singularnosti objekta u odnosu sa uslovima konteksta i asimilacija karaktera pojedinačnih elemenata u fluidni karakter celine. Na taj način, arhitektonske projektantske principe karakteriše disperzija disciplinarnih granica i granica unutrašnjosti i spoljašnjosti, hibridnost i gubitak tipoloških definicija. Ovaj rad prikazuje kako dematerijalizacija arhitektonskih vrednosti transformiše savremeni arhitektonski prostor u kompleksan dinamički sistem infrastrukture, tokova, događaja i efekata.

KLJUČNE REČI: ARHITEKTONSKA ESTETIKA, ARHITEKTONSKO PROJEKTOVANJE, ESTETSKO ISKUSTVO, DINAMIČKE VREDNOSTI, FLUIDNOST, GLOBALIZACIJA

\section{KINEMATOGRAFIJA I ARHITEKTURA: MODERNA PERCEPCIJA Sônia Campaner Miguel Ferrari}

Esej Valtera Benjamina (Walter Benjamin) o bioskopu objašnjava njegove prognostičke vrednosti. Dok je pisao ovaj članak, njegova kritika kapitalističkog načina produkcije pokazala je pravac u kojem kapitalizam napreduje: ka sve većoj eksploataciji proletarijata, ali i ka svom vlastitom padu. Nas zanimaju ove prognoze koje potvrdjuju transformaciju umetnosti i njene funkcije, a koja našu pažnju usmeravaju na gubitak transcedencije i opadanja aure umetničkog dela. One u isto vreme pokazuju mogućnosti kojima se potvrđuje kontinuitet umetnosti koja ima drugačiju ulogu i dislokacija aure. Oblik umetnosti koji je pogodan za ovakvo razmišljanje je kinematografija i paralela koju je filozof povukao izmedju kinematografije i arhitekture. Namera nam je da se osvrnemo na ovu paralelu i urbane intervencije kao umetničke oblike estetske modernosti: to 
jest, kao proizvode ove modernosti koji istovremeno ukazuju na način koji nam je dat i shvaćen. Takodje ćemo se osvrnuti i na indikacije bioskopa i pozorišta kao načina da se prevazidju telesne odrednice koje nam se nameću.

KLJUČNE REČI: ARHITEKTURA, BIOSKOP (KINEMATOGRAFIJA), MODERNA UMETNOST, MODERNA PERCEPCIJA, URBANIZAM

\section{AUTORSTVO I JEZIK U KNJIGAMA SAVREMENIH ARHITEKATA}

\section{Deniz Balık Lökçe}

Ovaj rad se bavi ispitivanjem teorijskih, grafičkih i materijalnih dimenzija savremene kulture štampe u arhitekturi sa fokusom na po jedno delo iz različitih evropskih praksi. Knjiga savremenog arhitekte posmatra se kao spekulativni i diskurzivni predmet dizajna. Mišel Fuko (Michel Foucault), posebno u svojim delima, Šta je autor? (1969) i Arheologija znanja (1972), kritikuje to da se prilikom izrade opusa jednog autora alternativni i neklasifikovani žanrovi izostavljaju iz domena, a tekstovi koji se vezuju za jedno ime pripadaju sistemu homogenosti, veze i recipročnog objašnjenja. Ipak, knjiga savremenog arhitekte proširuje granice žanrova tako što je sačinjena od nekonvencionalnih materijala, poput muzičkih nota, umetničkih fotografija, slika, tehničkih i naučnih dijagrama, zvaničnih izveštaja, gradjevinskih propisa, novinskih članaka i reklama, a takođe i od kombinacije tekstova i fotografija saradnika, partnera, klijenata i korisnika, a ne samo kao produkt jednog autora. Ovaj rad se bavi tumačenjem korišcenja različitih oblika grafičke naracije i spajanja nove terminologije i žargona kao doprinosa moći jezika i diskurzivnoj formaciji.

KLJUČNE REČI: ARHITEKTONSKI MEDIJI, ARHITEKTONSKA MONOGRAFIJA, KNJIGA, FUKO, ŽANR, KULTURA ŠTAMPE, AUTOR, TEKST

\section{ARHITEKTURA KAO TEKSTUALNI FENOMEN: APROPRIJACIUSKE ARHITEKTONSKE PRAKSE ALEKSANDRA BRODSKOG Boško Drobnjak}

Tekst analizira arhitekturu nastalu aproprijacijom postojećih materijala fokusirajući se na strategije intertekstualnosti. Rad zastupa tezu da značenje arhitektonskog objekta ne proizlazi iz njega samog ili njegovih poetskih koncepata, već iz njegovih odnosa sa drugim arhitektonskim objektima, drugim umetničkim delima kao tekstovima, kulturalnim tekstovima i svakodnevnim životnim praksama. Cilj rada jeste da se pokažu različiti teorijski problemi teorije arhitekture i umetnosti koji kao mreža uodnošenih tekstova kulture okružuju arhitektonsku produkciju Aleksandra Brodskog (Alexander Brodsky). Za metod rada je karakteristično operisanje sa različitim i raznorodnim teorijskim konceptima, uzimajući odabrane studije slučaja (Votka paviljon i Rotunda) arhitekture Brodskog u okviru koje je rad koncipiran kao interdisciplinarna studija.

KLJUČNE REČI: ALEKSANDAR BRODSKI, APROPRIJACIJA, SVET UMETNOSTI, EKSPERIMENTALNA ARHITEKTURA, READY-MADE, TEKST

\section{PITER AJZENMAN I MOGUĆNOST ESTETSKOG FORMALIZMA \\ Amund M. Rolfsen}

Formalna razmatranja predstavljaju srž aspekta rada Piter Ajzenmana (Peter Eisenman). Može se tvrditi da su ona jedina dosledna tema njegovog rada, i zasnivaju se na konceptu da je arhitektura posredovanje izmedju otelovljenog unutrašnjeg sveta ljudskih bića i spoljnog fizičkog sveta koji naseljavamo. Ajzenman tako daje „konceptualnu“, a ne percepcijsku osnovu, pri čemu su univerzalni formalni odnosi važniji od čulnih aspekata. Na taj način arhitektura ostaje kao 